\title{
El Espacio Orfico de la Novela en \\ La Muerte de Artemio Cruz
}

\begin{abstract}
Una novela es un espejo: todos lo dicen. Pero ¿qué es leer una novela? Creo que es saltar al espejo. De repente se encuentra uno al otro lado del cristal en medio de gentes y cosas familiares al parecer. Pero es un mero parecer, en realidad nunca les habiamos visto. $\mathrm{Y}$ las cosas de nuestro mundo han pasado fuera, a su vez, y se han vuelto reflejos.

J.P.SARTRE, Situations I, p. 14.
\end{abstract}

Al comentar su novela ante E. Carballo, Carlos Fuentes no dejó de indicar la doble tensión que la disgrega entre los polos opuestos de la vida y la muerte:

Se relatan aquí las doce horas de agonía de este viejo que muere de infarto al mesenterio (...) En su agonía, Artemio trata de reconquistar, medio por de la memoria, sus doce días definitivos, días que son en realidad doce opciones. ${ }^{1}$

Así abre el autor un espacio de extrañamiento en el que su personaje cobra de repente un valor arquetípico, volviéndose la expresión íntima del vivir agónico mexicano, el punto de encuentro de las fuerzas antagónicas que configuran el destino de su país:

Entre nosotros (...) no hay un solo tiempo (... ) Nuestro tiempo se nos presenta impuro, cargado de agonías resistentes. La batalla es doble: luchamos contra un tiempo que, también, se divierte con nosotros, se revierte contra nosotros, se invierte en nosotros, se subvierte desde nosotros, se convierte en nombre nuestro. ${ }^{2}$

Si escribir es precisamente, como lo afirma Fuentes, este contratiempo, la novela no puede entenderse como una "Vida de Artemio Cruz" por muchos datos biográficos que contenga. Tampoco se reduce a la relación contemporánea de una agonía, ya que ésta forma un simple paréntesis dentro del conjunto. Ni se puede asimilar a la crónica de setenta y un años de historia, vistos a través de un individuo ejemplar. Parece más bien encauzada hacia distinto rumbo, a la otra orilla donde la muerte consagra el nacimiento de la obra. Tal vez el gran mérito del mito griego sea habernos señalado este oscuro origen del arte. Orfeo canta en Eurídice nostalgia de la unidad perdida, su pasión plantea el dilema de la otredad. La trayectoria de Artemio parte de una misma disyuntiva; ha de reproducir, en algún modo, el errático vaivén de su paradigma eterno. $\mathrm{El}$ " 'moriré" que cierra el libro remite la muerte a un futuro posterior, asignando al relato un papel de pretexto. Opera una total inversión de valores: el final hecho principio. Al proyectar sobre la vida de Artemio la mirada neutra de la muerte, el autor pretende descubrir la otra cara de su medalla,-empresa sumamente azarosa-, por eso le marcó la frente con una cruz en señal de albur. ¿No sería ésta la "equis" que cifró, para Alfonso Reyes, el enigma mismo de México?

${ }^{1}$ En Diecinueve protagonistas de la literatura mexicana del siglo $X X$ (México: Empresas Editoriales, S.A., 1963), pp. 440-441.

${ }^{2}$ Carlos Fuentes, Tiempo mexicano (México: Cuadernos de Joaquín Mortiz, 1972), pp. 9-10. 
Paradoja de la muerte: oscura y silenciosa, no contesta a nuestra interrogación y su negativa llena de estupor helado nuestro discurso. Es también el instante supremo que "iguala el origen con el destino", devolviendo de él una imagen definitiva que permite abarcarlo en su totalidad. "Animal que prevés tu muerte, cantas tu muerte, la dices, la bailas, la pintas, la recuerdas. .. " (p 278) ${ }^{3} \mathrm{Al}$ apostrofar así a su personaje, Fuentes plantea en sus términos eternos la exigencia de su propia tentativa. Conocido es el caso de estos "resucitados" que creyeron revivir, en "un abrir y cerrar de ojos", su existencia de pronto desarrollada como en una película. Nuestro concepto de la muerte cobra entonces su pleno valor de metáfora de la vida. ${ }^{4}$ Es el sitio de una extraña bipartición. En un sentido, exalta el "yo", otorgando la mirada para atrás, hacia las cosas, con la que alcanza su esencia oculta. En otro, todo tiene un aspecto más verdadero pero también más alejado. Quizá sea porque no me puedo referir nunca a la experiencia propia. Así la mayor exaltación del individuo es siempre la del Otro visto como un no ser, nadie. La muerte ningunea.

$\mathrm{Al}$ presentar su novela como un "diálogo de espejos", ", Fuentes hizo mucho más que retomar un tópico. Llevó hasta sus últimas consecuencias una frase de $\mathrm{O}$. Paz para quien "la muerte es un espejo que refleja las vanas gesticulaciones de la vida'. Su propia expresión es mucho más compleja y deliberadamente equívoca. Pudo serle dictada por la misma ambiguedad del tema. Sugiere una infinita combinación de efectos visuales y sonoros a partir de un foco perpetuamente eludido. Construcción abismal en torno a una ausencia.

En efecto, todo el relato está comprendido en el espacio que separa un par de miradas al espejo. Nunca tenemos de Artemio una visión directa. Al abrir los ojos, en la primera página, descubre, y nosotros con él, su "nueva cara" de enfermo, cara de espanto, reflejada en "las incrustaciones de vidrio de una bolsa de mujer"' (p. 9). La fuerte impresión que le procura el esperpento le hace cerrar otra vez los ojos:

Trato de recordarlo en el reflejo; era un rostro roto en vidrios, sin simetría, con el ojo muy cerca de la oreja y muy lejos de su par, con la mueca distribuida en tres espejos circundantes (p. 10).

No los vuelve a abrir sino muy contadas veces hasta el final, cuando divisa de nuevo sus facciones deformes en un cristal colocado encima de la mesa de operación. Este enfoque parece inspirarse en una previa lectura de Sombras, novela corta de Jaime Torres Bodet. Doña Eulalia, la protagonista, aislada del mundo por su egoísmo, su vanidad y su orgullo, vive retraída en una casa poblada de recuerdos. Al sentir que se le acerca la muerte, echa una última mirada al espejo, "duda de pronto (. . .) y por primera vez, no se reconoce", 6 . Algo muy parecido le ocurre a este hombre de rostro desconocido, que trata de hurtarse a la vista cerrando los ojos. A falta de retrato suyo, no tenemos más remedio que asentar su escasa presencia en elementos sumamente precarios: unas cuantas frases truncas obsesivamente repetidas, retazos de diálogo con los comparsas del drama y, sin embargo, a diferencia de ellos, no dejamos de oír el eco de su voz muda, voz del silencio, salida de las profundidades de su ser intimo. Fuentes establece así, entre personaje y lector, una relación totalmente ficticia dentro de la particular obliteración del monólogo interior.

${ }^{3}$ Los números de las páginas citadas corresponden a la primera edición (México: F.C.E., 1962).

${ }^{4}$ Véase Edgar Morin, L'bomme et la mort (Paris: Seuil, 1970), p. 22 ss.

${ }^{5}$ E. Carballo, op. cit., p. 441.

${ }^{6}$ Sombras (México: Editorial Cultura, 1957), p. 143. 
Son islotes de conciencia que, en medio de un característico estado de duermevela, expresan, a través de numerosos altibajos y frecuentes interrupciones, el caos del trance mortal. Por medio de este recurso, nos es dado reconstituir, a ciegas y con deliberada inexactitud, todo un ajetreo fúnebre, en las idas y venidas de los próximos (miembros de la familia, secretario, médicos) entre los cuales destaca la figura de un sacerdote cuya presencia señalan un insistente "olor de incienso" y la visión nebulosa de unos "faldones negros". El relato de la agonía desgrana todo el ritual de preces y unciones rematado por la recitación del "De profundis" (p. 248) y una significativa señal de la cruz a medio hacer. Pero, al mismo tiempo, está puntuado en sordina por las violentas reacciones de un hombre que aprendió desde joven a "odiar a los curas". Nace así la impresión de que estamos presenciando un simulacro de muerte cristiana. Para refor zar el ambiente carnavalesco de este primer nivel narrativo y con el fin de infundirle mayor distancia literaria, el autor parece haber retomado en tono paródico los procedimientos del Ars Moriendi,cuyo esquema tradicional reproduce escrupulosamente. ${ }^{7}$ Artemio ha de sucumbir a las cinco grandes asechanzas mediante las cuales solia el demonio, según las leyes del género, disputar a los ángeles el alma del moribundo. Primero, el renegar de la fe, entre encarnizadas blasfemias dirigidas " a la virgen azorada que se había creído los cuentos y supercherías de su familia" (p. 30), al hijo del carpintero "con sus doce agentes de relaciones públicas"' (p. 88), al sacerdote venido a auxiliarle, "que voluntariamente se disfraza de mujer, que voluntariamente se castra, que voluntariamente se emborracha con la sangre ficticia de un Dios"' (p. 123). Segundo, la mala conciencia, al repasar mentalmente los errores cometidos evocando los nombres de quienes murieron por él: "Yo sobreviví. Regina. ¿Cómo te llamaban? No. Tú Regina. ¿Cómo te llamabas tú, soldado sin nombre? Sobreviví. Ustedes murieron. Yo sobreviví" (p. 85, 222). Tercero, el apego a las riquezas: mientras imagina a su mujer y a su hija despojándole de sus bienes, evoca desesperadamente "El ruido fresco y dulce de billetes y bonos nuevos (...) el arranque suave de un automóvil de lujo... (p. 163). Cuarto, la desesperación por los sufrimientos: “( $(.$.$) no quiero esa piel azul, esa piel pintada de sangre muerta, no, no, no$ la quiero, azul otra cosa, azul el cielo, azul los recuerdos, azul los caballos que cruzan los ríos..." (p. 221). Quinto, la soberbia: “(...) todo o nada: ¿conocen mi albur? ¿lo entienden? (...)" con guevos, jugándosela, rompiéndose la madre, exponiéndose a ser fusilado por los de arriba o por los de abajo; eso es ser hombre como yo he sido. . "' (p. 120). El texto recalca el efecto haciendo coincidir el momento crucial de la absolución con el delito mayor de la apostasía:

Eso sí existe, eso sí es mío. Eso sí es ser Dios, ¿eh?, ser temido y odiado y lo que sea, eso sí es ser Dios, de verdad ¿eh? Dígame cómo salvo todo eso y lo dejo cumplir todas sus ceremonias, me doy golpes en el pecho, camino de rodillas hasta un santuario, bebo vinagre y me corono de espinas (p. 163).

Paradójicamente, Artemio se condena en nombre de una moral que todo su ser rechaza. Por más que la rechace, muere "con todos los auxilios de la Santa Madre Iglesia"' (p. 30). La parodia sirve aquí para resquebrajar la fachada de honradez y respetabilidad impuesta por la decencia, detrás de la cual se disimula un profundo desasosiego interior. Otro "rito" interfiere con éste, destinado a acreditar una nueva versión del personaje. En las horas que preceden su traslado a la

${ }^{7}$ Dicha comparación nos fue inspirada por el ensayo de Paul Westheim, La calavera, trad. Mariana Fuente (México: Ediciones Era, 1971). 
clínica, mandó traer a su cabecera una grabadora en la que solía registrar sus conversaciones de negocios. Oye así su "voz reversible", que le suena tan chillona a los oídos, cuando arman el aparato. En los intervalos de escucha, ésta restaura la imagen del potentado de la víspera, la del hombre sin escrúpulos, listo para acudir a todos los expedientes, a todos los compromisos con tal de lograr su meta. Semejante impronta pugna por sustituirse a la impresión anterior, consiguiendo en su estridencia reforzar el efecto general de ocultación. Artemio desaparece otra vez tras su deseo de perseguir, hasta en los umbrales de la muerte, la quimera de un poder que por fin le abandonó.

Cabe añadir que, al presente del relato, se superponen otros niveles narrativos aparentemente desconectados entre sí. Con "las doce horas de agonía", alternan los "doce días definitivos" de Artemio que vuelve a aparecer desde el seno de su desaparición. Son reflejos de reflejos, imágenes en segundo grado repercutidas por los múltiples espejos del texto: aguas del recuerdo, cristal de una mesa, vidrieras de un vestíbulo, mar de sueños, río remoto o mirada ajena, que siempre representan una visión parcial del personaje. En su silueta borrosa, destacan las manos, los pies. Se concentra la atención en los ojos verdes y la frente marcada por la cicatriz, únicas señas de identidad en sus facciones cambiantes. Del mismo modo, pasamos de una faceta a otra de su personalidad sin saber cuál elegir. El voluntario anacronismo del relato remite adrede a los papeles sociales más discordes, a las aspiraciones íntimas menos compatibles, hasta configurar el espectáculo de una radical enajenación. Tenemos incluso la impresión sugerida por la sintaxis del texto, que los diversos episodios de la novela hubieran podido integrar doce vidas distintas, cuando descubrimos de pronto que el único día auténtico de Artemio ha sido vivido por otro, Lorenzo su hijo. Pero el autor no deja de poner en tela de juicio su propia sugerencia:

Elegirás entre los espejos infinitos uno solo que te reflejará irrevocablemente, que llenará de una sombra negra los demás espejos, los matarás antes de ofrecerte, una vez más, esos caminos infinitos para la elección (p. 209).

Estamos ante el retrato vivo de la mala conciencia. ${ }^{8} \quad$ Simétrica de sí misma, la frase refleja los días definitivos como otras tantas elecciones malogradas. Todo juicio definitivo sobre esta vida raya en ilusión. El diálogo de espejos concluye en moderna variante del mito de Eco y Narciso. Al acercarse a su intimidad más profunda, repite Artemio el absurdo movimiento de la Bestia, en La madriguera de Kafka. Siempre se aleja de sí para dar con el Otro que viene a su encuentro, consiguiendo tan sólo en su ceguera, oír el eco desesperado de su propia marcha:

Recordarás otras cosas, otros días que llegarán de noche a tu noche de ojos cerrados y sólo podrás reconocerlos por la voz: jamás con la vista. Deberás darle crédito a la noche y aceptarla sin verla, creerla sin reconocerla, como si fuera el Dios de todos los días: la noche (p. 35).

Hero el eclipse de Artemio preside a la aparición de lo invisible, cuando la agonía opera en sus ojos la inversión suprema del éxtasis. Así inaugura el autor la mirada órfica, que no lo quiere en su verdad diurna, sino en su extrañeza misma, hasta lograr en ella la plenitud de su muerte.

8 “'La mala conciencia (...) está rodeada por todas partes de superficies reflejantes en las que rebotan los problemas. Por todas partes las cosas le devuelven su propia imagen: quisiera escaparse y por todas partes vuelve a encontrarse a sí misma." V. Jankelevitch, La mauvaise conscience (Aubier-Montaigne, 1966), p. 19. 
Al plasmar en salto mortal el acceso a la otredad, la obra vuelve a abrirse dentro de su cerrazón inicial. Enlaza el fin con el comienzo, confiriéndole al personaje el carácter indefinible de la semcjanza cadavérica y un puro destino de aparecido. "Cuando el futuro es suprimido-apunta Fuentes en Tiempo mexicano-el origen ocupa su lugar". Esta "certeza acaso revestida de mitos" deja traslucir un asomo de la teoria junguiana de los "arquetipos". Sugiere otra lectura tendida hacia el oscuro trasfondo de la novela, ahí donde ha de revelarse la imagen primordial.

"Despierto" - la ambiguedad empieza con la primera palabra. Además de señalar la salida del anterior colapso, el verbo retoma puntualmente la fórmula consagrada que, según los informantes de Sahagún, marcaba para los antiguos mexicanos, el paso a mejor vida. Así encauzado, el relato de la agonía, con su letanía de frases obsesivas de doble sentido, "abran la ventana", "cruzamos el río a caballo", evoca una oscura migración del alma. Como si el moribundo, en el acto de alcanzar la otra orilla, pugnase por recobrar la unidad perdida, con el fin de no caer en la sima de Mictlán, "el lugar sin puertas ni ventanas". De hecho, Artemio trata constantemente durante su agonía de "encontrar los cabos" del hilo roto por él en su afán de " completar (su) otro destino, la segunda parte que (él) no pudo cumplir". Consta observar que la humanidad, hija de la Noche y del Viento, tiene en la tradición órfica del huevo de Fanés-o de Metis ${ }^{9}$ - el mismo origen dual que en la mitología náhuatl. Situándose en el punto de convergencia de corrientes tan diversas, Fuentes supo aprovechar la magnífica ocasión que se le ofrecía de enfocar la búsqueda de la identidad dentro de un espacio híbrido donde escapase siempre en radical otredad. Por eso, aquí, la curva de la reminiscencia abandona la circularidad del modelo griego para convertirse en parábola de Quetzalcóatl.

La escena inicial parece directamente sacada de los anales de Cuautitlán ${ }^{10}$ Tras descubrir su imagen monstruosa empañada por el "vahovahovaho" de su respiración, Ártemio, presa de un repentino acceso de dolor que lo hace ovillarse sobre sí mismo, vuelve a divisarla en otro espejo colocado frente a su cama. Sin lugar a dudas, el atributo dos veces caracterizado, esas manos y esos pies reunidos por el escorzo del ademán, son una alusión transparente al espectro de Tezcatlipoca configurado por sus únicas manifestaciones visibles. Esta brutal revelación le inspira entonces al personaje las palabras que perpetraron la caída de Quetzalcóatl: "Pido, pido que mi rostro y mi cuerpo me sean devueltos" (p. 10). El autor sólo altera la letra de la leyenda para recalcar su terrible poder de remanencia: en etecto, todo el itinerario mental del personaje se inscribe dentro de una infinita sospecha circular.

Probablemente inspirado por las teorías de Northrop Frye, René Jara C. no dejó de aclvertır la impronta dei mito azteca, señalando la coincidencia de la antigua fiesta del Fuego Nuevo con un episodio de particular relevancia en la novela. Al celebrar en Coyoacán sus 52 años de vida pública, Artemio actúa a manera de oficiante en un ritual que lo hace participar del ritmo cíclico del universo. Así, cada recuerdo suyo, con estar incluído en un contexto histórico muy preciso, viene a superar la "contingencia temporal" "11. Semejante opinión rebasa el punto de vista

${ }^{9}$ Por más señas véase Orpbeus and Greek Religion, trad. francesa por S.M. Guillemin: Orphée et la religion grecque (Paris: Payot, 1956).

${ }^{10}$ Fuentes nos propone su propia interpretación de la leyenda y un comentario de los Anales en Tiempo mexicano, op. cit. Véase "De Quetzacóatl a Pepsicóatl,"' pp. 17-23.

${ }^{11}$ René Jara C., "El mito y la nueva novela hispanoamericana. A propósito de La muerte de Artemio Cruz" (En Homenaje a Carlos Fuentes, Madrid: Anaya, 1971, pp. 149-208. 
subjetivo desde el cual el autor enfoca su novela, para atenerse a sus implicaciones últimas. Parece preciso matizarlo, notando que, al repasar por vía de la memoria las distintas circunstancias de su vida, Artemio Cruz trata más bien de eludir la contingencia a punto de anegarle definitivamente. Incluso, en última hora, aparece movido por el poderoso afán de sobrevivir, reencarnando en los demás: Lorenzo, su hijo, a quien imagina cumpliendo su otro destino, las mujeres amadas que constituyen la otra mitad de su ser. Semejante anhelo explica la relativa hipertrofia del tema amoroso. Este rebasa en gran parte el simple interés romántico que le concedió injustamente J. Sommers ${ }^{12}$. La Revolución representa otra etapa esencial de la conversión interior que se está operando. En el acto mágico, por el que el héroe, aplicándole las palabras de Octavio Paz, "Se adentra en sí mismo, en su pasado y en su sustancia, para extraer de su intimidad, de su entraña, su filiación". La lógica misma del proceso recurrente acaba superponiendo a la perspectiva de la muerte el recuerdo del nacimiento: impone la imagen de la madre estrechamente ligada a la de la tierra. Así concluye el retorno al origen rumbo al Este y ai mar. Por ahí ha ce pasar la "ruta psicológica de Quetzalcóatl", que va siguiendo Artemio. Pero, conforme se afirma su conciencia moral en el gesto de la mano tendida, con "sus cinco estrellas contráctiles, sus cinco dedos clavados en la otra orilla"' (p. 208), pierde su figura individual para integrar el Todo. Dos escenas-claves, enmarcando el relato, rematan el efecto de cosmización: arrebatado en éxtasis, lleva en su cuerpo, como 'bajel de piedra", las huellas que dejó la " "tropa ruda isabelina:" (p. 35), al desembarcar algún día por las playas de Vera Cruz, de donde salió, él mismo, siguiendo allende los montes, la antigua ruta de los invasores, en busca de su propio centro; " vas a ser el punto de encuentro y la razón del orden $\iota$.iversal ${ }^{14},(\ldots)$ eres, serás, fuiste el universo encarnado" (p. 313), reza finalmente el texto. Un mismo espacio onírico de mainifiestas consonancias heraclíteas, consigue, pues, anular los tres tiempos, otorgando una primera visión de la muerte. Al querer fundirse en el mundo, él intenta alcanzar la libertad del ser que le permitiría transcender su efímera condición de hombre. Al menos, ésta es la ilusión profética que le procura su éxtasis de ojos cerrados.

Pero el espejo mágico de Tezcatlipoca se los abre otra vez, devolviéndole la imagen cotidiana de su otra muerte, la que no dejó de perseguirle durante su vida. "La cueva desde la cual acecha al hombre-observa Paul Westheim-no sólo es un lugar, es un pasado mítico, es horror a un pretérito que Tezcatlipoca puede convertir de nuevo en presente o futuro'. Dentro del orden circular, vuelve a nacer en sentido contrario, el fluir temporal. Al polo materno se sustituye entonces el polo paterno como fuente de destrucción. "'Isabel Cruz o Cruz Isabel"' (p. 314) es la clave de la inversión que se opera en el destino de Artemio cuando, tras oír en la montaña el "aooo prolongado de Lunero" (probable alusión al "cerro del grito" donde los toltecas invocaron por primera vez a Tezcatlipoca ${ }^{15}$ ) inicia su salida para el Oeste, siguiendo a la luz del día el curso de la Historia.

\footnotetext{
12 "Individuo e historia" (En La novela bispanoamericana actual, Las Américas-Anaya, 1971, pp. 147-155).

13 Jorge Carrión, Mito y magia del mexicano (México: Ediciones Nuestro Tiempo, 1970), pp. 38-51.

${ }^{14}$ No se expresa de otro modo Laurette Sejourné en su famoso estudio: " "(...) el hombre, por pertenecer a la vez a los abismos opacos y a los esplendores celestes, constituye el terreno de reencuentro fuera del cual los principios opuestos morirían en el aislamiento"' (En Pensamiento y religión en el México antiguo (México: Breviarios, F.C.E., No. 128, p. 131). La interpretación existencialista de la novela por Cath. Mc. Allen (Homenaje, op. cit., pp. 399-442) encuentra allí sus raices más profundas.

${ }^{15}$ Véase Walter Krickeberg, “El pecado de Quetzacóatl," p. 50, (En Mitos y leyendas de los aztecas, incas, mayas y muiscas, México: F.C.E., 1971).
} 
La carrera del personaje, con sus características fases de sol y sombra, parece entonces dominada por el antagonismo de los astros gemelos de la antigua cosmogonía. Fruto de una violación, prematuramente huérfano, presenta todos los síntomas del muy mexicano "complejo del hijo pródigo"'. Sus ademanes de macho mal consiguen disimular un homosexualismo laîente, como lo atestiguan la prístina educación en rodillas del maestro Sebastián y el estrecho abrazo con los cuates, en casa de la Saturno. Será pues el hombre de la traición, cuya actitud pública hecha de coyotaje, lambisconería, malinchismo, deriva exactamente de la dialéctica de la soledad. Apéndice del capitalismo norteamericano al que sirve de prestanombre, cortesano supremo de la "República Hereditaria" a través de los órganos de prensa que dirige, este potentado vive parapetado detrás del poder. Llega a ser la personificación del tapadismo oculto en la "sonriente ezquizofrenia" denunciada por Fuentes como el estigma indeleble de la Revolución instituçional. Unas mismas señales de debilidad repercuten hondamente en su vida privada. La suerte le depara en Regina, Laura, Catalina, Lilia, "la mujer" ' que amó "con ses cuatro nombres distintos" (p. 122), - las cuatro doncellas reservadas a las víctimas de Tezcatlipoca. Semejante fatalidad acaba por reducir progresivamente sus relaciones amorosas a las proporciones de una mera gesticulación. Vuelve a señalarlo con particular encono el juego de los pies condenados a errar por un laberinto cuya complejidad señaia el aporte de nuevas influencias. Artemio, al dejar la "media luna veracruzana", está destinado a tener "otra historia", guiado por "la mano lánguida del México $\operatorname{seco}(.$.$) atada por hilos dorados a las Antillas, al Océano y, más allá, al$ Mediterráneo" (p. 278). Como,Orfeo, es víctima de un mismo "error geográfico" que le hizo abandonar las languideces del Golfo para radicarse, después de una siempre maléfica incursión en el Norte, en el bárbaro Anháuac. Su matrimonio fracasado, con sus alternativas de unión nocturna y de separación diurna, no deja de evocar también el drama de Psique. Catalina, simbólicamente sentada "con el espejo en una mano" (p. 167), vuelve a aparecerle como "la ninfa enemiga", " "el doble" que le significa su derrota al esposo ansioso de recobrar en el amor su alma perdida. Al mirarle a cara descubierta, le condena, dignándose tan sólo compartir con él, cuando ya es demasiado tarde, la amargura de una "inútil caricia" (p. 28, 204). No hay tal " "ninfa del orgullo"' (p. 97), sin embargo, los demás detalles de la frase permiten identificarla como Calisto metamorfoseada por Zeus en la última estrella de la Osa Mayor. Así connotada, la vuelta insidiosa del tema de Tezcatlipoca no ha de sorprender. Además de expresar el sincretismo de la agonía, pone de manifiesto la vcluntaria confusión de los planos. Todo concurre, pues, a hacer de Artemio la puesta de un "siniestro juego de eliminaciones"' (p. 196), en el que, a pesar de sus efímeros triunfos, fatalmente ha de llevar las de perder. Con muy certera técnica, a medio libro, estalla la cruda verdad'de su herencia, en grito desgarrador:

(...) hijos de la chingada, la chingada que envenena el amor, disuelve la amistad, aplasta la ternura, la chingada que divide, la chingada que separa, la chingada que destruye, la chingada que emponzona (. . .) (p. 146).

Tantos días "mutilados", señalados de negro, confieren ahora al "sobrevivir" del personaje un escaso valor de plazo a punto de vencer. Regina, el soldado herido, Gonzalo, Lorenzo asociados varias veces er. otra de las frases obsesivas del texto y hasta el padre Páez, todas esas muertes ajenas son augurios de la suya. Esta se vuelve patente en la frtografía que pretende eternizar su figura de momia lista para emprender el último viaje, con debido acompañamiento de mastines. Ultimamente, la agonía remata el efecto, superponiendo a la imagen del niño extático de la montaña, la del enfermo en su lecho de muerte. Con esta última visión de un hombre que sólo vivió "vida muerta" (p. 34) acaba de cerrarse la curva de la parábola. 
En el acto de morir, el antiguo mexicano podía contemplar su rostro eterno en el "espejo humeante''de Tezcatlipoca. Allí veía sellada su desdicha, como si el dios de la incertidumbre sólo le hubiera colmado de favores para ordenar mejor su castigo. Alli veía sus pecados ritualmente plasmados en forma de excrementos. $\mathrm{El}$ autor reanuda con esta remota fuente de inspiración al enlazar una fría y clínica descripción de infarto al mesenterio (p. 90-91), con el instante de la revelación suprema en que lo horrible muestra las entrañas del ser. Vuelve a imponerse el tema de la caída de Quetzalcóatl. Presa de un mismo acceso de terror sagrado, Artemio experimenta, a su vez, señales de una obvia monstruosidad: un "olor de escamas muertas" (p. 203), unas contracciones "como los anillos de una serpiente" (p. 220). La agonía perpetra un total estado de enajenación rematado por ambiguas connotaciones religiosas. Mientras el sacerdote le unta el óleo sacramental, el texto mantiene el equívoco dando la impresión de que es víctima de un sacrificio ritual: "alguien me ha clavado un puñal largo y frío en el estómago"' (p. 219). Los dos movimientos contrarios del libro se implican, alcanzado el paroxismo de la otredad. ' 'Ahí, en pleno salto-apunta $\mathrm{O}$. Paz-el hombre, suspendido en el abismo, entre el esto y el a.juello, por un instante fulgurante es esto y aquello, lc que fue y lo que será, vida y muerte, en un serse que es un pleno ser, una plenitud presente"' ${ }^{16}$. Así pudiera ser de Artemio cuando, brutalmente yuxtapuesta a la del "corazón abierto" (p. 314), que parece marcar el apoteosis de su conversión, una últıma imagen nos lo muestra en el yuirofiano donde sufre una operación "inútil". El espejo, que lo había introducido, efectúa la salida del mito. Por ser evidente, ei encuentro con el autor de La noche boca arriba no deja de tener implicaciones radicalmente opuestạs. Fuentes destruye el efecto en el momento preciso en que Cortázar inicia el suyo. Artemio no puede participar un secreto que sólo poseerá cuando sus ojos se cierren para siempre. Cumple así un ciclo celebrado de antemano en las viejas crónicas, el de un pueblo "cuyo rostro nadie conocía", el mismo destino de la serpiente emplumada. Al romper la fatalidad de su máscara, se convierte otra vez en desconocido.

Plasmada en triple nexo mitológico, la muerte de Artemio Cruz no pretende imponer de él una imagen definitiva. Ora se inspira, de mala manera, en el Calvario de Cristo crucificado en medio de mujeres orantes. Ora éstas, empeñadas en echar mano de su testamento, revuelcan la habitación como furias, listas para iniciar una suerte de "sparagmos" órfico. Ora creemos presenciar el desenlace sangriento de una "guerra florida", cuando el cuchillo ritual desgarraba las entrañas de la víctima sacrificada en aras de una terrible fatalidad. Así, alcanzado este punto desde el cual " 'la vida y la muerte, lo real y lo imaginario, el pasado y el futuro, lo comunicable y lo incomunicable, dejan de ser percibidos contradictoriamente" ${ }^{17}$, el personaje vuelve a reflejarse en el mismo texto hasta tomar la forma del eternamente disperso.

"La muerte-escribe Jankelevitch-juega al escondite con la conciencia: donde estoy, no está, y cuando está, ya no estoy yo. Mientras soy, la muerte está por venir, y cuando sobreviene aquí y ahora, ya no hay nadie'18 . Esta disyuntiva repercute en la escritura de la novela. Más allá del artificio aparente, traduce la voluntad de rebasar los límites individuales, abarcando la totalidad del ser-para-la-muerte. Tampoco deja de recordar una observación de Michel Butor:

\footnotetext{
${ }^{16}$ El arco y la lira (México: F.C.E., 1970), p. 180.

${ }^{17} \mathrm{La}$ cita es de A. Breton en la traducción de Fuentes (Véase Tiempo mexicano, op. cit., p. 12).

${ }^{18}$ La mort (París: Flammarion, 1966), p. 31.
} 
"cada vez que hay relato novelesco, las tres personas del verbo entran obligatoriamente en juego: dos personas reales: el autor que cuenta la historia, que correspondería en la conversación corriente al 'yo', el lector, a quien la cuentan, el 'tu', y una persona ficticia, el héroe, de quien cuentan la historia, el 'él' ,' 19 Así, Fuentes, al sistematizar el uso de los pronombres, somete su personaje a una constante modificación en la que nos convida a participar.

Los fragmentos en primera persona figuran la experiencia imperfecta de la muerte propia. Balbuceos de una conciencia cerrada que se expresa en presente, remiten a un porvenir que "el viejo moribundo no alcanzará a conocer'. Al contrario, los pasajes en tercera persona cubren la mayor parte de la narración. Ecos pretéritos de una memoria anónima hablando desde el seno del olvido, dejan oír el discurso inconsciente del Otro, como un recordar sin reposo. A medio camino, una voz franquea el muro que separa el monólogo interior del relato impersonal:

Hay un tercer elemento, el subconsciente, especie de Virgilio, que lo guía por los doce círculos de su infierno, y que es la otra cara de su espejo, la otra mitad de Artemio Cruz: es el "Tú"' que habla en futuro. ${ }^{20}$

La referencia a Virgilio confirma la inspiración órfica de una obra fundada en la constante rotación de sus signos. Imagen especular del yo, la segunda persona, límite próximo de la otredad, consigue la partición del sujeto. Se inicia pues, por dobles interpuestos, un muy lacaniano juego a cuatro entre personaje y lector en que le toca a éste hacer de muerto ${ }^{21}$. En efecto, la escritura efectúa el paso de "Yo', a 'El", mediante el cual, según Blanchot, "lo que me ocurre a mí, no le ocurre a nadie, es anónimo porque me concierne, se repite con una dispersión infinita". Inversamente, advierte M. Butor, "lo que se me cuenta es siempre alguien que se cuenta y me cuenta'. Mi lectura opera pues el retroceso de la tercera a la primera persona. Pero mientras el aoristo mítico se actualiza en el presente del relato, el discurso en segunda persona cargado de un alto valor profético, al reflejar en futuro el pasado de Artemio, hace de lo vivido algo imposible de vivir y que, por lo tanto, ha de trastornar los datos de la existencia. Así, el concierto de las "voces" interfiere tiempos y espacios por medio de un sistema de transgressiones cuyo efecto es borrar el límite que separa el orden de la narración del orden de lo narrado. En este tipo de relato giratorio que evita la cerrazón del mensaje final para reanudar sin tregua su movimiento entre vida y muerte, no " habla" la obra sino para repetir lo que constituye, en la formulación de Freud, el dicho de la cosa: "Ahí donde érase, he de venir a ser'".

Sin embargo, el eterno retorno de lo mismo excluye la presencia en beneficio de la representación. En el escenario de la escritura, vivo el simulacro de la muerte de Artemio Cruz según las reglas de un juego que acaba de constituir el texto en espacio de diferencia. Cada elemento llamado presente remite a otro y, sin dejar de conservar la huella del pasado, lleva ya la impronta del futuro, estando siempre en relación con lo que no es él, dentro de un haz de relaciones entrecruzadas que no llegan a coincidir hasta el final:

${ }^{19}$ Essais sur le roman (París: Gallimard, Idées No. 188), p. 73.

${ }^{20}$ Entrevista de E. Carballo en Diecinueve protagonistas, op. cit., p. 440.

${ }^{21}$ Por más señas, véase Jacques Lacan, Ecrits I, "La chose freudienne," Coll. Points, pp. 209-248. 
Yo no sé. . . no sé. . . si él soy yo. . . si tú fue él. . . si yo soy los tres. . . Tú. . . te traigo dentro de mí y vas a morir conmigo. . . los tres. . . que hablaron. . . Yo. . . lo traeré adentro y morirá conmigo... solo. . . (p. 315).

Hay un "yo no sé" que está al margen del saber, observa M. Blanchot. La frase enuncia lo fragmentario en un lenguaje que no lo reconoce, como si el discurso circular tuviera por contenido su propia continuidad. "La palabra incluye siempre subjetivamente su respuesta", precisa asimismo Lacan, al evocar un sistema de comunicación en que el emisor recibe del receptor su propio mensaje en reverso. En semejante dialéctica estriba para nosotros la explicación de una estructura hasta hoy más controvertida que cabalmente justificada por la crítica. Por más moderna que parezca, no deja de reanudar con el antiguo arte de los "Tlamatinime", que suplían las insuficiencias de su escritura jeroglífica con el auxilio de la tradición oral. En efecto, como si pusiera particular esmero en seguir el modelo de los anales nahuas, Fuentes encabezó los distintos episodios de su novela con fechas muy precisas. Estas cubren la casi totalidad del año (suprema libertadc del autor, el mes de marzo no viene en la cuenta); así adquieren los " 12 días definitivos de Artemio", a manera de "nemontemi" o de "cabañuelas", un ambiguo valor de enmascarados. Coinciden los más notables de ellos, con fechas fatídicas del calendario sagrado: nace el 9 de abril de 1889--dominado por la cifra 9 maléfica del "tonalámatl" -y muere el 10 de abril de 1959--día de cifra 10, dedicado a Tezcatlipoca, cuya fiesta, observa Sahagún, caía cerca de la Pascua cristiana. Resta observar cómo el conjunto de los 38 fragmentos, sutil combinación entre los 12 círculos del infierno dantesco y los 13 cielos aztecas, con su particular distribución en 3 series iniciadas por sendos pronombres del paradigma verbal, adopta cual "rueda de los años", la forma característica del Códice en cruz. Allí pudo encontrar Fuentes, además de un título, lo más claro de su inspiración. Por lo visto, la escritura fragmentaria de la novela lleva un "espacio de lenguaje al límite desde el cual vuelve la irregularidad de otro espacio hablante/ no hablante $^{, 22}$, destinado a interpolar con el primero. Da el paso más allá en que Artemio pierde su escaso valor de personaje para cobrar su auténtica dimensión de texto.

En plena ausencia, y como por omisión, algo se cumple sin cumplirse, que me aparta de mí mismo para identificarme con el Otro. Entonces no es la muerte la que comparto con él, sino el puro morir, la pérdida intransitiva "en un movimiento de pura pasividad". Desde esta perspectiva de incesante muerte y resurrección, de unidad que se resuelveen otredad para recomponerse en nueva unidad, acaso sea posible penetrar en el enigma de la obra. Entre las piedras de un relato caótico, la "otra voz"' tiende el puente del deseo, un deseo que se transfigura a fin de alcanzar su objeto materialmente vedado. Así, tres veces ordenada en los planos temático, mítico y textual, la disolución del personaje preside a su reencarnación en el lector. Hecho co-partícipe de la obra, éste ha de reinsertar el mensaje perdido en los blancos de la escrutura. "Poesía, momentánea reconciliación", escribe O. Paz, "Todos los hombres son este hombre que es otro y yo mismo. Yo es tú y también él y nosotros vosotros y esto y aquello" ${ }^{23}$. Artemio Cruz, de probable estirpe india, hijo de mulata y criollo, es la encarnaicón misma de un pueblo traumatizado por el choque de una historia de simultaneidades, de aparentes cabos sueltos, de promesas truncas e incumplidas. Incapaz de "pensar en blanco y negro, en buenos y malos, en Dios y Diablo", (p. 33), viene a ser la expresión intima del dilema mexicano. Pero la

\footnotetext{
${ }^{22}$ Maurice Blanchot, Le pas au-delà (Paris: Gallimard, 1973), p. 72.

${ }^{23}$ El arco y la lira, op. cit., p. 181.
} 
huella se borra al presentarse; sólo permanecen en escena frases y pensamientos fingidos, meras simulaciones del ser. Afirman un tiempo sin presente en que no tengo lugar. A través de Artemio, me alcanza la tentación de otra desgracia. Siempre ha muerto en mí. Sólo veo en él la sombra de mi identidad perdida.

Estas consideraciones marcan el fin de nuestra propia búsqueda. Permiten combinar la interpretación realista de Nelson Osorio, empeñado en restaurar el orden del relato, ${ }^{24}$ con el análisis estructuralista de René Jara que hace del personaje una "revelación mítica del ser americano". Pretenden reconciliar la aseveración rotunda de Emmanuel Carballo para quien la novela es "la democición de un mito" ${ }^{25}$ con la hipótesis adversa de Manuel Durán según la cual "Fuentes nos muestra otra cara del mito del Rey Viejo" ${ }^{26}$. Todas estas lecturas pecarían de parciales de no tener en cuenta el dinamismo interno de una obra en perpetua ruptura, en perpetuo trance de renovación. "Ni Huitzilopochtli, ni Torquemada, ni Rockefeller; pero sí Netzahualcoyotl, Goya y Whitman'” asienta el autor de Tiempo mexicano. La indole órfica de su inspiración había de resolver la crisis de identidad a partir de sus mismos fundamentos, plasmando la "lucha del discurso lineal de occidente con el fantasma del tiempo cíclico indígena" hasta crear "una espiral poética en la que tiempo y lenguaje, resistiéndose el uno al otro, no repiten el pasado sino que fundan de nuevo el origen". México puede serlo todo, concluye Fuentes, indio, mestizo y occidental, sin abocarse a la fatalidad, con tal de sustituir a los espacios de la opresión los tiempos de la libertad. El retorno al mito desemboca en una reconquista de la Utopía.

Abrir los ojos o cerrarlos, todo es igual?

(...) hacía allá, al centro vivo del origen, más allá de fin y comienzo.

O. Paz, El cántaro roto

“Libro de pinturas es tu corazón" rezan dos versos del manuscrito Romances de los Señores de la Nueva España. Al plasmar en su libro el corazón abierto de Artemio, Fuentes no hace más que tomar al pie de la letra el viejo precepto. Quizá movido al optimismo por su contacto con la revolución cubana, haya optado por resolver la disyuntiva de México en términos de reconciliación. Le sirve de divisa una cita de Montaigne repetida en el texto (p. 249), "la premeditación de la muerte es premeditación de la libertad". De ahí el sentido profético de una de sus últimas advertencias indirectamente dirigidas al lector:

Tú serás ese niño que sale a la tierra, encuentra su destino, hoy que la muerte iguala el origen y el destino y entre los dos, clava, a pesar de todo, el filo de la libertad (p. 279).

La frase suena como una invitación urgente a buscar anclaje en el tiempo, cogiendo este hilo de Ariadna tan tenue que sólo permite salir del laberinto de la soledad. Asimismo, la obra asocia la antigua sabiduría náhuatl a la griega, oponiendo al espectro de "la muerte pelona" una sintesis

\footnotetext{
24 ، "Un aspecto de la estructura de La muerte de Artemio Cruz", (En Homenaje..., op. cit., pp. 127-146).

25 “ 'La actual literatura mexicana"' (En Panorama de la actual literatura latinoamericana, La Habana: Casa de las Américas, 1969, p. 10).

${ }^{26}$ Triptico mexicano (México: Sep-Setentas, No. 81, 1973). p. 65
} 
novedosa tendida hacia la búsqueda de un verdadero modelo de vida. "Conocedor de la región de los muertos", el totecatl, recuerda Miguel León-Portilla ${ }^{27}$ "era precisamente "el-quecolocaba-espejos-ante-los-demás", induciéndoles hacerse "dueños de su corazón". "Ladrón de flores y cantos", tenía la facultad de enseñar a mentir a las cosas. Incrustando símbolos en el mundo que antes carecía de alma, conocía la única manera de decir palabras verdaderas en la tierra. La noche órfica en que Fuentes desarrolla su diálogo de espejos reanuda hondamente con este poder de disimulación que preside a todo arte. Señala la máscara detrás de la cual se oculta el rostro de ese Alguien que es la esencia de todos los hombres. Así entendido, el texto de la novela, según la expresión de Derrida, " "no está rodeado sino atravesado por sus límites, marcado desde adentro por el surco múltiple de sus márgenes. Propone a la vez el monumento y el espejismo de la huella, la huella simultáneamente trazada y borrada, simultáneamente viva y muerta, viva como siempre de simular también la vida en su inscripción guardada'. ${ }^{28}$ Orfismo, búsqueda de una cuarta dimensión-decía Apollinaire-aquí expresión de lo innominable. Fuentes nos hace compartir el riesgo absoluto de inscribir un suplemento a su "códice en cruz", al otro lado de la página.

\section{Université de Caen}

BERNARD FOUQUES

\footnotetext{
${ }^{27}$ Los antiguos mexicanos a través de sus crónicas y cantares, (México: F.C.E., 1970).

${ }^{28}$ Jacques Derrida, "La différence"' (En Marges de la pbilosophie, París: Minuit, 1972, p. 25).
} 